\title{
Antioxidant, antimicrobial and antiproliferative activities of fungal metabolite produced by Aspergillus flavus on in vitro study
}

\author{
Taghreed N. ALMANAA ${ }^{1 *}$ (D), Gamal RABIE ${ }^{2}$ (D), Rasha M. El-MEKKAWY², Marwa A. YASSIN ${ }^{2}$, Noha Saleh ${ }^{2 *}$ (D), \\ Nashwa EL-Gazzar²
}

\begin{abstract}
Regarding to the defiance came upon scientists to output natural products with potent biological activity from cheap sources and in an attempt to recover the average of antiproliferative agents, the employment of fungal metabolite in creating a cordial proper process was a prerequisite. In the present results, fungal metabolites were detected by thin layer chromatography. One fungal isolate out of ten isolates bioassayed, was showed to have the most potent antioxidant, antiproliferative and antimicrobial activity; this fungal isolate was identified as belonging to Aspergillus flavus (A. flavus). Fungal extract of A. flavus showed a high free radical scavenging activity using Diphenyl-1-picrylhydrazyl (DPPH) scavenging \% with low a concentration of IC $_{50}$ and potent flavonoid content. The result of instrumental analysis using GC.Mass illustrates the presence of different potent products of A. flavus extract. In addition, A. flavus extract showed a promising antiproliferative activity. Inhibitory activity against Hepatocellular carcinoma cells was detected under these experimental conditions. This strategy can be further used to elicit new age drugs.
\end{abstract}

Keywords: Aspergillus flavus; bioactive compounds; GC; DPPH; antibacterial; antifungal.

Practical Application: The present study confirmed the efficient role of fungal bioactive products as strong in vitro antioxidant, antimicrobial and antiproliferative activities. The results indicated that the A. flavus had a potent naturalistic constituent in cytotoxicity. In addition, these natural sources constituent have recently shown a promising interest in treating cancer or inhibiting multidrug pathogenic bacteria.

\section{Introduction}

The existence of numerous issues of cancer disease and antibiotic resistant strains is increased recently and their inhibition by alternative agents are necessary (Shi et al., 2007; El-Gazzar et al., 2020; Abdel-Shafi et al., 2020; Enan et al., 2020; El-Sayed et al., 2020). In addition, the biocontrol of this cancer is of interest to persist study to detect and discover newly solution to prevent such disease in vitro (Shi et al., 2007).

In this regard, there is an inevitable and urgent medical need for natural bioactive metabolites with novel anticancer and antimicrobial activity (Abdel-Shafi et al., 2020; Enan et al., 2018) and there is frequently concern in detection protocols to create confident and appreciate-efficient biocidal products (El-Gazzar et al., 2020; El-Gazzar \& Ismail., 2020).

Recent perspectives all over the world are to use safe materials as either safe therapy or as a biosorptive tools for anticancer and antimicrobial activity (Enan et al., 2020; Abdel-Shafi et al., 2020; Osman et al., 2021). In this framework, natural metabolites from fungi are also used to create confident and appreciate-efficient biocidal products by applying the material technology, industrial processes and others (El-Gazzar et al., 2020). For a wide variety of secondary metabolites, fungi are the most diverse, where different primary extracts play a powerful role in the biological activity of species (Ronsberg et al., 2013; El-Gazzar \& Enan, 2020). Recently, research procedures have been undertaken for various fungi that have confirmed their function in curative fields (Simmons et al., 2005). Derivative extracts from fungal strains are distinguished by incoming inherent outputs that are subject to characterize new medicine and industries (Suryanarayanan et al., 2009).

Numerous bioactive metabolites isolated from Aspergillus sp. were published in several literatures (Huang et al., 2009).These metabolites, such as anticancer, antimicrobial and antioxidant activities have shown therapeutic importance. The biological importance of these fungal species is of great interest to the scientific community. In order to detect compounds with successful anticancer activity, there are criteria to continue testing. This research seeks to detect the function of Aspergillus flavus bioactive metabolites as an anticancer, antibacterial and antioxidant agent.

\section{Materials and Methods}

\subsection{Fungal strains used:}

The fungal strains used in this study were isolated from soil contaminated with wastes from Photographic Industries (El-Sharkia Governorate, $80 \mathrm{~km}$ North Cairo, Egypt) (El-Gazzar, 2015). They were purified and finally grown in slants of Czapeks Dox agar 
medium. The isolates were purified using Potato Dextrose agar (PDA media) (glucose- yeast extract - potato filtrate) as reported by El-Gazzar (2015) and identified according to Raper \& Thom (1949); Raper \& Fennell (1965) and Booth (1971).

\subsection{Preparation and extraction of fungal metabolite:}

The fungal cultures used in this investigation were subjected for spore production through the growing of the tested fungi on PDA broth (Oxoid) medium at about one week at $28 \pm 2{ }^{\circ} \mathrm{C}$. The spore suspension was purified and filtered by cheesecloth. Spores were enumerated by qualified hemocytometer. A convenient attenuation was prepared using the supply spore narrator through sterilized $0.1 \%(\mathrm{w} / \mathrm{v})$ peptone water as diluents to take out the in demand spores level of $4 \times 10^{2}$ cells $/ \mathrm{mL}$ (Abdel-Salam et al., 2001; Enan etal., 2013).

Fungal metabolites were extracted from the mycelium that inoculated in a sterilized Czapek Dox Broth $(100 \mathrm{~mL})$ at $121^{\circ} \mathrm{C}$, $15 \mathrm{lbs}$ pressure for 15-20 min in Erlenmeyer flask and incubated in dark $\left(10 \mathrm{~d}, 25 \pm 1{ }^{\circ} \mathrm{C}\right)$.

The fresh mycelial mat of each fungal strain was ground in a mortar in the presence of sterile fine sand and methanol: chloroform $(1: 2 \mathrm{v} / \mathrm{v})$ to extract the secondary metabolites then centrifuged and filtered. The solvent was evaporated, using an air drier and the metabolites were dissolved in methanol and stored at $5{ }^{\circ} \mathrm{C}$ (El-Gazzar et al., 2020; El-Sayed et al., 2020).

The broth filtrates were defatted with n-hexane, then collected and taken away using methanol: chloroform $(1: 2 \mathrm{v} / \mathrm{v})$ in a separating funnel, shaken well and left at least for six hours until complete separation from the lower phase. Sediment was re-taken away again for full separation by evaporation of solvents and the metabolites were dissolved in methanol and stored at $5{ }^{\circ} \mathrm{C}$ (Abdel-Salam et al., 2001).

\subsection{Detection of fungal extracts with TLC}

The thin layer chromatography was employed successfully for the separation of different bioactive compounds (Dedio et al., 1969). The broth filtrates can be applied on thin layer chromatography TLC plates. Developing processes can be carried out, using chloroform: methanol $(9: 1 \mathrm{v} / \mathrm{v})$ system for separation of fungal secondary metabolites.

\subsection{Free radical scavenging activity of the fungal extract}

The antioxidant efficiency of the methanolic extract was determined with the standard of their scavenging efficiency of the 1,1- diphenyl-2-picryl hydrazyl (DPPH) free radical (Melo et al., 2008; Baba \& Malik, 2015). Briefly, $10 \mu \mathrm{L}$ of each extract $(50 \mu \mathrm{g} / \mathrm{mL})$ were mixed with $3.8 \mathrm{~mL}$ of DPPH solution and incubated at $37^{\circ} \mathrm{C}$ for 30 minutes. The absorbance of the mixture was examined at $517 \mathrm{~nm}$. Ascorbic acid was used as a positive standard. The study was performed in triplicate. Scavenging efficiency rate was determined using the subsequent Formula 1:

Scavenging activity $(\%)=\frac{\text { A control }- \text { A sample }}{\text { A control }} \times 100$

\subsection{Determination of Total Flavonoid Content (TFC)}

The TFC of the fungal extracts was determined by aluminum chloride colorimetric assay. The absorbance of each mixture was determined at $510 \mathrm{~nm}$ against the same mixture but without fungal extracts as a blank. TFC was determined as $\mu$ g quercetin equivalent per mg of samples with the help of calibration curve of quercetin. All determinations were performed in triplicate $(n=3)$.

\subsection{Determination the $\mathrm{IC}_{50}$ of Free radical scavenging activity and TFC for the most active fungal extract}

$100 \mu \mathrm{L}$ of diverse concentrations prepared from the stock of the most active fungal extract $(800 \mu \mathrm{g} / \mathrm{mL})$. From this stock extract $(800 \mu \mathrm{g} / \mathrm{mL})$, different dilutions were made to contain 5 , $10,20,40,80,160,320$ and $640 \mu \mathrm{g} / \mathrm{mL}$, respectively. Serial two-fold dilutions of fungal extract were made in sterile deionized water by taking $0.00625,0.0125,0.025,0.05,0.1,0.2,0.4$ and $0.8 \mathrm{~mL}$, from the original stock and this equals $5,10,20,40,80,160$, 320 and $640 \mu \mathrm{g} / \mathrm{mL}$, respectively. The $\mathrm{IC}_{50}$ of The antioxidant efficiency of these different concentrations of fungal extract was determined with the standard of their scavenging efficiency of the 1,1-diphenyl-2-picryl hydrazyl (DPPH) free radical (Melo et al., 2008) as mentioned above in subsection 2.4. In addition $\mathrm{IC}_{50}$ of TFC of these different concentrations of fungal extract was determined by aluminum chloride colorimetric assay as mentioned above in subsection 2.5 .

The $\mathrm{IC}_{50}$ of ascorbic acid (standard antioxidant) determined by taking different concentration from stock ascorbic acid $(100 \mu \mathrm{g} / \mathrm{mL})$, different dilutions were made to contain 5,10 , $15,20,25,30,35$ and $40 \mu \mathrm{g} / \mathrm{mL}$, respectively. Serial two-fold dilutions of ascorbic acid were made in sterile deionized water by taking $0.05,0.1,0.15,0.2,0.25,0.3,0.35$ and $0.4 \mathrm{~mL}$, from the original stock and this equals $5,10,15,20,25,30,35$ and $40 \mu \mathrm{g} / \mathrm{mL}$, respectively.

\subsection{Antimicrobial assay using fungal extract}

The sediment of the most potent fungal extract (A. flavus extract) was re-taken away again after extraction of secondary metabolites as mentioned above in subsection 2.2.for full separation by evaporation of solvents and the metabolites were dissolved in DMSO. Stock preparation of fungal extract $(200 \mu \mathrm{g} / \mathrm{mL})$ was prepared and then stored in Eppendorf tubes (Gomhuria Co., Zagazig, Egypt) at $5{ }^{\circ} \mathrm{C}$ until antimicrobial activity tests were performed.

Antibacterial activity of the most potent fungal extract was evaluated against Staphylococcus aureus DSM 1104, Streptococcus pyogenes ATCC 19615, Escherichia coli LMG 8223 and Pseudomonas aeruginosa LMG 8029. Stock bacterial cultures were routinely sub-inoculated in brain heart infusion broth (BHIB) (Oxoid) (Enan et al., 2013; Abdel-Shafi et al., 2016), and then kept at $4{ }^{\circ} \mathrm{C}$ for uses in this investigation. Brain Heart infusion agar plates (DifcoTM, Maryland, USA) were prepared and seeded with log phase cells $\left(10^{5} \mathrm{CFU} / \mathrm{mL}\right)$ of bacterial inoculants. Each test organism $(100 \mu \mathrm{L})$ was mixed with cooled Mueller-Hinton agar and poured into $80 \mathrm{~mm}$ petri dishes; then the sterile singly stock preparation of fungal 
extract $(200 \mu \mathrm{g} / \mathrm{mL})$ was applied to discs $(6 \mathrm{~mm}$ diameter $)$ which were added onto the above plates. All samples were incubated at $37{ }^{\circ} \mathrm{C}$ for $24-48 \mathrm{~h}$. Inhibition zone diameters (IZDs) were determined (Abdel-Shafi et al., 2016, 2020; El-Gazzar \& Enan, 2020; Aziz et al., 2014). Gentamycin was used as positive control. All experiments were performed in triplicates.

Antifungal activity of stock preparation of fungal extract $(200 \mu \mathrm{g} / \mathrm{mL})$ was evaluated against Candida albicans and Fusarium oxysporium by agar disc diffusion method. The plate incubated at $37^{\circ} \mathrm{C}$ for 5-7 days and the zones of inhibition were measured. Ketaconazole was used as positive control. All experiments were performed in triplicates for statistical analysis.

\subsection{Antiproliferative activity of the most potent fungal secondary metabolites by cell lines}

The cell lines were maintained in Roswell Park Memorial Institute (RPMI) 1640 medium (Life Technologies, Inc., Grand Island, NY) supplemented with $50 \mu \mathrm{g} / \mathrm{mL}$ gentamycin and $10 \%(\mathrm{v} / \mathrm{v})$ heat inoperative fetal bovine serum (FBS) and developed at $37^{\circ} \mathrm{C}$ in $5 \% \mathrm{CO}_{2}$ (Water Jacketed Double door incubator, Shel Lab, Sheldon Manufacturing, Inc. ${ }^{\oplus}$, USA) about 48 hrs. Samples were examined with an inverted microscope (CKX41; Olympus, Japan) to check the cultures and to confirm their sterility from contamination by microorganisms. Cells layer rinsed using phosphate buffered saline, $\mathrm{pH} 7.2$ without $\mathrm{Ca} 2+/ \mathrm{Mg} 2+$, a volume equal to semi the cultivated medium size. Trypsin/ EDTA was introduced into the rinsed single layer cell using $1 \mathrm{~mL}$ per $25 \mathrm{~cm}^{2}$ of surface area and left in $37^{\circ} \mathrm{C}$ about 5 minutes. Then, the samples were examined by a microscope to confirm their detached and floated. They were combined with new FBS containing RPMI environment. The count of samples was measured by taking away 100-200 $\mu \mathrm{L}$ from their followed by trypan blue dye exclusion method using a hemocytometer. The demanded count of samples was put in plates supplied with growth environment then kept as recommended for the cell line (Mosmann, 1983; Vijayan et al., 2004).

\subsection{Estimation the antiproliferative efficiency}

The antiproliferative activity was evaluated on single carcinoma cell lines, namely Liver hepato cellular cells (HepG2). The cell line was originated as mono layers with 10 per cent (v/v) inoperative foetal calf serum and $50 \mu \mathrm{g} / \mathrm{mL}$ gentamycin in the growth medium. The single layers of 10,000 organisms subjected at down of the 96 -bore plate kept at $37^{\circ} \mathrm{C}$ about $24 \mathrm{~h}$ and $5 \% \mathrm{CO}_{2}$. The cells were then rinsed by phosphate buffered saline ( $0.01 \mathrm{M}$; pH 7.2); then they were subjected by $100 \mu \mathrm{L}$ of diverse concentrations prepared from stock extract of $A$. flavus $(1000 \mu \mathrm{g} / \mathrm{mL})$ or pure metabolites new environment and kept at $37^{\circ} \mathrm{C}$. From this stock extract of $A$. flavus $(1000 \mu \mathrm{g} / \mathrm{mL})$, different dilutions were made to contain $3.9,7.8,15.6,31.25$, $62.5,125,250$, and $500, \mu \mathrm{g} / \mathrm{mL}$, respectively. Serial two-fold dilutions of $A$. flavus extract were made in sterile deionized water by taking $0.0039,0.0078,0.0156,0.03125,0.0625,0.125$, 0.25 , and $0.5 \mathrm{~mL}$, from the original stock and this equals 3.9 , $7.8,15.6,31.25,62.5,125,250$, and $500, \mu \mathrm{g} / \mathrm{mL}$, respectively. The control of unhandled cells was applied without strains products.
Then, the count of handled cells was determined after one day of incubation by staining these cells with crystal violet $(0.1 \%$, w/v) subsequence with rapture using 33\% glacial acetic acid and examining at $590 \mathrm{~nm}$ using ELISA (Model: Sunrise, Tecan Inc., USA) after good combination. The readings of controlled cells were pointed as $100 \%$ proliferation $(23,24)$. The rate of cell efficiency was measured by the subsequent Formula 2:

Cell efficiency $(\%)=1-\frac{\mathrm{ODt}}{\mathrm{ODc}} \times 100$

Whereas, ODt is the medium optical density of the strain product handled wells and ODc is the optical density medium of the control sample (Abdel-Shafi et al., 2020).

\subsection{Gas chromatography and mass spectrometry analysis of the most active A. flavus extract}

The stock extract of $A$. flavus $(200 \mu \mathrm{g} / \mathrm{mL})$ was dissolved in DMSO. To determine and identify the bioactive compounds of A. flavus extract, Gas Chromatography-Mass Spectroscopic (GC-MS) was used (Trace GC 1310-ISQ Mass Spectrometer, Thermo Scientific, Austin, TX, USA) at Department of fungi, Al-Azhar University, Egypt. A direct capillary column TG-5MS $(30 \mathrm{~m} \times 0.25 \mathrm{~mm} \times 0.25 \mu \mathrm{m}$ film thickness $)$ was used. About $3 \mu \mathrm{L}$ of $A$. flavus extract was injected automatically to the equipment using Auto sampler AS3000 coupled with GC in the split less mode. The procedure was integrate canicular line (DB1 J\&W; $30 \mathrm{~m}$ length; $0.25 \mathrm{~mm}$ Inner diameter; $1.5 \mathrm{um}$ film thickness), that synthetically fixed dimethyl polysiloxane. The procedure was adjusted at $40^{\circ} \mathrm{C}(1 \mathrm{~min})$ then elevated to $250{ }^{\circ} \mathrm{C}(2 \mathrm{~min})$ at a rate of $5^{\circ} \mathrm{C} / \mathrm{min}$ and then elevated to $310^{\circ} \mathrm{C}(2 \mathrm{~min})$ at a rate of $5^{\circ} \mathrm{C} / \mathrm{min}$. The temperature for the detector and the injector was set at $300^{\circ} \mathrm{C}$. The components were identified by comparison of their retention times and mass spectra with those of WILEY 09 and NIST 11 mass spectral database (Enan et al., 2020).

\subsection{Statistical analyses}

The data obtained were conducted in triplicates and results were expressed using subjected to one-way ANOVA analysis for estimating means and standard deviations $( \pm S D)$. Post hoc: Duncan's multiple comparisons, to determine the significant variations among the various parameters in the experimental groups. All of the statistical analyses were performed using SPSS version 14 (SPSS, Chicago, IL, USA). A P value of $<0.05$ was considered statistically significant.

\section{Results}

The obtained data in Table 1 emphasized that preliminary identification of the ten fungal isolates, by international Reference Key. The results confirmed the presence of different significant antioxidant activities in the most cases between the different tested fungi as shown in Table 1 and Figure 1. The antioxidant activity of the extracellular extracts are higher than the intracellular extracts of the fungal isolates. Whereas, the antioxidant activity of intracellular extracts was recorded only in A.flavus, Trichoderma sp, A.terrus, A.oryza and A. flavups at $\% 61.5 \pm 1.15,49.6 \pm 0.55$, $21.1 \pm 0.55,19.2 \pm 0.60$ and $15.9 \pm 0.56$, respectively. On the 
Table 1. Fungal secondary metabolites separated on TLC and its antioxidan activities of conc. ( $50 \mu \mathrm{g} / \mathrm{mL})$.

\begin{tabular}{|c|c|c|c|c|}
\hline \multirow{2}{*}{ No. } & \multirow{2}{*}{ Fungal isolates } & \multicolumn{2}{|c|}{ DPPH scavenging \% } & \multirow{2}{*}{$\frac{\text { Flavonoid content }}{\text { Flavonoid content }(\mu \mathrm{g} / \mathrm{mg} \text { quercetin })}$} \\
\hline & & Intra. & Extra. & \\
\hline 1 & Aspergillus flavus & $61.5 \pm 1.15$ & $81.4 \pm 0.60$ & $469 \pm 1.25$ \\
\hline 2 & Aspergillus fumigatus & - & $48.9 \pm 1.19$ & $367 \pm 1.22$ \\
\hline 3 & Aspergillus terrus & $21.1 \pm 0.55$ & $68.2 \pm 1.19$ & $332 \pm 1.2$ \\
\hline 4 & Penicillium chrysogenum. & - & $22.9 \pm 1.31$ & $182 \pm 1.19$ \\
\hline 5 & Fusarium moniliform & - & $17.6 \pm 0.52$ & $134 \pm 0.85$ \\
\hline 6 & Fusarium oxysporium & - & $11.8 \pm 0.45$ & $129 \pm 0.85$ \\
\hline 7 & Penicillium citrinum. & - & $21.6 \pm 0.16$ & $178 \pm 1.19$ \\
\hline 8 & Aspergillus flavups & $15.9 \pm 0.56$ & $33.3 \pm 0.76$ & $166 \pm 0.65$ \\
\hline 9 & Trichoderma sp & $49.6 \pm 0.55$ & $79.1 \pm 0.56$ & $221 \pm 0.45$ \\
\hline 10 & Aspergillus oryza & $19.2 \pm 0.60$ & $42.5 \pm 0.45$ & $218 \pm 0.45$ \\
\hline
\end{tabular}

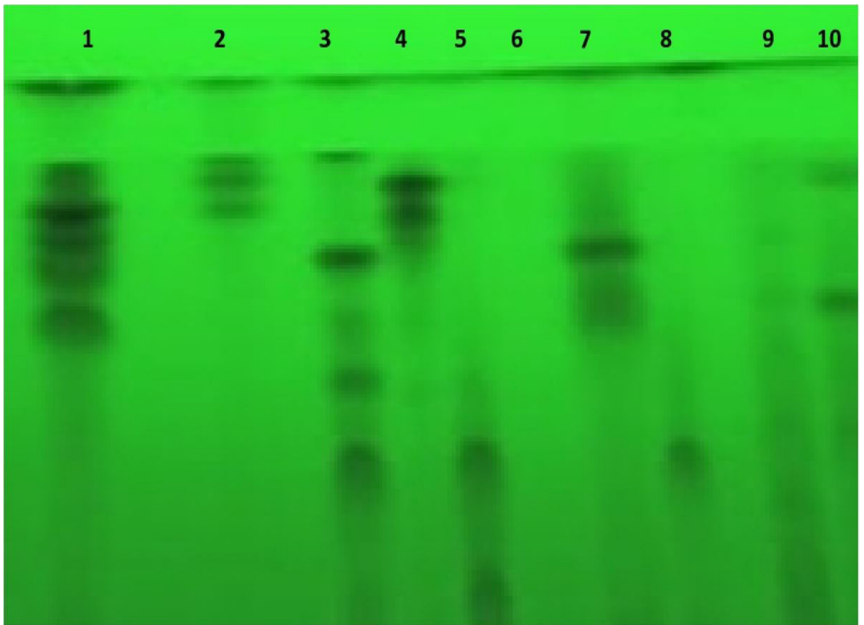

Figure 1. Separation of extracellular secondary metabolites on TLC plate under short wavelength UV light. Where, the numbers from 1 to 10 are the numbers of fungi in the Table 1.

other hand, the antioxidant activity of extracellular extracts was recorded in all tested fungal isolates. However, weak antioxidant action was examined in extracellular outputs \% (22.9 \pm 1.31 , $21.6 \pm 0.16,17.6 \pm 0.52$ and $11.8 \pm 0.45$ ) of fungal isolates, Penicillium chyrsogenum, Pencillium citrinium, F.moniliform and F.oxysporium, respectively. On the other hand, marked antioxidant action was investigated in the extracellular outputs $\%(48.9 \pm 1.19,42.5 \pm 0.45$ and $33.3 \pm 0.76)$ of fungal isolates A. fumigatus, A. flavups and A. oryzea, respectively. In addition, strong antioxidant activity was detected in the extracellular extracts \% $(81.4 \pm 0.60,79.1 \pm 0.56$ and $68.2 \pm 1.19)$ of fungal strains, A. flavus, Trichoderma sp and A. terrus, respectively. The data presented in Table 1 showed a different flavonoid contents between the various tested fungi. Whereas, the most potent antioxidant activity is presented with $A$. flavus extract using DPPH at \% $81.4 \pm 0.60$ with flavonoid concentration at $\% 469 \pm 1.25 \mu \mathrm{g} / \mathrm{mg}$ compared the other tested fungal isolates.

From Table 1 and Figure 1, it was shown that fungal secondary metabolites constitute from a huge array of low molecular weight natural products. In addition, the presence of a wide range of chemical diversity after application on TLC silica gel plate, Figure 1. Whereas, methanol and chloroform were mandatory used as they were the best two solvents for extraction of the secondary metabolites from fungi compared with other solvents used in the extraction (data unpublished). Extractability of the tested solvents was arranged in following descending manner: chloroform and methanole $>$ diethyl ether $>$ ethyl acetate $>$ benzene $>$ petroleum ether $>$ hexane $>$ Acetonitrile $>$ toluene. So, the developing solvent system (chloroform and methanol) in the ratio 9:1 $\mathrm{v} / \mathrm{v}$ optimized for separation of the secondary metabolites into individual metabolites.

The A. flavus extract showed an antioxidant activity under these experimental conditions with $\mathrm{IC}_{50=} 5 \mu \mathrm{g} / \mathrm{mL}$ as shown in Table 2. In addition, the $\mathrm{IC}_{50}$ of a significant flavonoid activity of the most potent $A$. flavus extract was evaluated at $5 \mu \mathrm{g} / \mathrm{mL}$ (Table 2). Moreover, the sample of ascorbic acid reference standard showed the most powerful natural antioxidant activity under these experimental conditions at $\% 92.48 \pm 2.48$ with $\mathrm{IC}_{50}=5 \mu \mathrm{g} / \mathrm{mL}$ as shown in the Table 3 .

From the data given in Table 4, high significant antibacterial activity was noted against some the tested pathogenic bacteria. The extract of $A$. flavus showed the most significant growth inhibition against Streptococcus pyogenes and Pseudomonas aeriginosa. On the other hand, there was a week significant growth inhibition against Staphylococcus aureus and E.coli compared with Gentamycin as a control.

The results obtained from Table 5 confirmed that there is a high significant antifungal activity of A.flavus extract against Foxysporium followed by Candida albicans. Whereas, the inhibition zone that formed by A. flavus extract against Foxysporium is more than that formed by applying the ketoconazole as a control (Table 5).

Inhibitory activity of metabolites extract of A. flavus against hepatocellular carcinoma cells was detected under these experimental conditions with $\mathrm{IC}_{50} 109 \pm 3.6 \mu \mathrm{g} / \mathrm{mL}$. as shown in Table 6 and Figure 2. Moreover, there is gradual decreasing of tumor cells when the concentration of fungal extract increased as shown in Figure 3a, b, c.

The GC.MS analysis of extracts of A. flavus culture filtrate gave us twenty six major compounds with potent antioxidant, antimicrobial and anticancer activities as shown in Figure 4 and Table 7. The bioactive substances were categorized in the following groups viz. flavonoids, phenols, alkaloids, terpenoids, 
Table 2. $\mathrm{IC}_{50}$ of antioxidant activity and flavonoid content of A. flavus extract.

\begin{tabular}{ccc}
\hline Sample conc. $(\mu \mathrm{g} / \mathrm{mL})$ & DPPH scavenging $\%$ & $\begin{array}{c}\text { Flavonoid content } \\
(\mu \mathrm{g} / \mathrm{mg} \text { quercetin })\end{array}$ \\
\hline 640 & $77.44^{\mathrm{a}} \pm 7.44$ & $121^{\mathrm{a}} \pm 1.21$ \\
320 & $64.33^{\mathrm{b}} \pm 4.33$ & $116^{\mathrm{b}} \pm 1.12$ \\
160 & $53.11^{\mathrm{c}} \pm 3.11$ & $101^{\mathrm{c}} \pm 1.0$ \\
80 & $42.22^{\mathrm{d}} \pm 1.89$ & $78^{\mathrm{d}} \pm 1.0$ \\
40 & $36.56^{\mathrm{d}} \pm 6.00$ & $53^{\mathrm{e}} \pm 0.85$ \\
20 & $18.33^{\mathrm{e}} \pm 3.33$ & $33^{\mathrm{f}} \pm 0.85$ \\
10 & $9.33^{\mathrm{f}} \pm 0.33$ & $16^{\mathrm{g}} \pm 1.19$ \\
5 & $7.59^{\mathrm{f}} \pm 1.59$ & $11^{\mathrm{g}} \pm 0.65$ \\
0 & $0 \pm 0.00$ & $0 \pm 0.00$ \\
\hline
\end{tabular}

Values with different superscripts within rows are significantly different $(\mathrm{P}<0.05)$.

Table 3. $\mathrm{IC}_{50}$ of antioxidant activity of ascorbic acid Reference standard.

\begin{tabular}{cc}
\hline Sample conc. $(\mu \mathrm{g} / \mathrm{mL})$ & DPPH scavenging \% \\
\hline 40 & $92.48^{\mathrm{a}} \pm 2.48$ \\
35 & $87.53^{\mathrm{b}} \pm 5.00$ \\
30 & $80.65^{\mathrm{c}} \pm 3.00$ \\
25 & $77.41^{\mathrm{c}} \pm 2.00$ \\
20 & $70.94^{\mathrm{d}} \pm 0.94$ \\
15 & $54.86^{\mathrm{e}} \pm 3.00$ \\
10 & $17.49^{\mathrm{f}} \pm 0.49$ \\
5 & $11.78^{\mathrm{g}} \pm 1.78$ \\
0 & $0^{\mathrm{h}} \pm 0.00$ \\
\hline
\end{tabular}

Values with different superscripts within rows are significantly different $(\mathrm{P}<0.05)$.

Table 4. Antibacterial activity of A.flavus extract.

\begin{tabular}{lcc}
\hline \multicolumn{1}{c}{ Tested bacteria } & Sample code & Control \\
\cline { 3 - 3 } & \multicolumn{1}{c}{ Inhibition } & Gone $(\mathrm{mm})$ \\
Gram Positive bacteria & $16^{\mathrm{b}} \pm 2.00$ & 23 \\
$\begin{array}{l}\text { Staphylococcus aureus } \\
\text { Streptococcus pyogenes }\end{array}$ & $19^{\mathrm{ab}} \pm 3.00$ & 25 \\
Atcc19615 & & \\
Gram negative bacteria & & 16 \\
Pseudomomas aeruginosa & $24^{\mathrm{a}} \pm 4.00$ & \\
LMG8629 & & 29 \\
Escherichia coli (LMG8223) & $20^{\mathrm{ab}} \pm 1.00$ & 25 \\
\hline
\end{tabular}

The test was done using the disc diffusion agar technique, well diameter: $6.0 \mathrm{~mm}(100 \mu$ was tested), The sample was tested T $200 \mu \mathrm{g} / \mathrm{mL}$ concentration. Values with different superscripts within rows are significantly different $(\mathrm{P}<0.05)$.

Table 5. Antifungal activity of A.flavus extract.

\begin{tabular}{lcc}
\hline \multirow{2}{*}{ Tested fungi } & Sample & Control \\
\cline { 2 - 2 } & Inhibition Zone $(\mathrm{mm})$ & \\
\hline Fusarium oxysporirum & $28^{\mathrm{a}} \pm 2.00$ & 25 \\
Candida albicans & $15^{\mathrm{b}} \pm 3.00$ & 20 \\
\hline
\end{tabular}

The test was done using the agar disc diffusion technique diameter: $6.0 \mathrm{~mm}(100 \mu$ was tested), The sample was tested $\mathrm{T} 200 \mu \mathrm{g} / \mathrm{mL}$ concentration. Values with different superscripts within rows are significantly different $(\mathrm{P}<0.05)$.
Table 6. Evaluation of cytotoxicity of A. flavus extract against HepG-2 cell line.

\begin{tabular}{cccc}
\hline Sample conc. $(\mu \mathrm{g} / \mathrm{mL})$ & Viability $\%$ & Inhibitory \% & S.D. $( \pm)$ \\
\hline 500 & 14.69 & 85.31 & 1.82 \\
250 & 26.71 & 73.29 & 0.97 \\
125 & 39.65 & 60.35 & 3.41 \\
62.5 & 79.21 & 20.79 & 2.78 \\
31.25 & 93.82 & 6.18 & 0.96 \\
15.6 & 99.43 & 0.57 & 0.43 \\
7.8 & 100 & 0 & \\
3.9 & 100 & 0 & \\
0 & 100 & 0 & \\
\hline
\end{tabular}

All experiments were carried out in triplicate. S.D. $( \pm)$ for the cell cytotoxic effect; three wells were used for each concentration of the test sample.

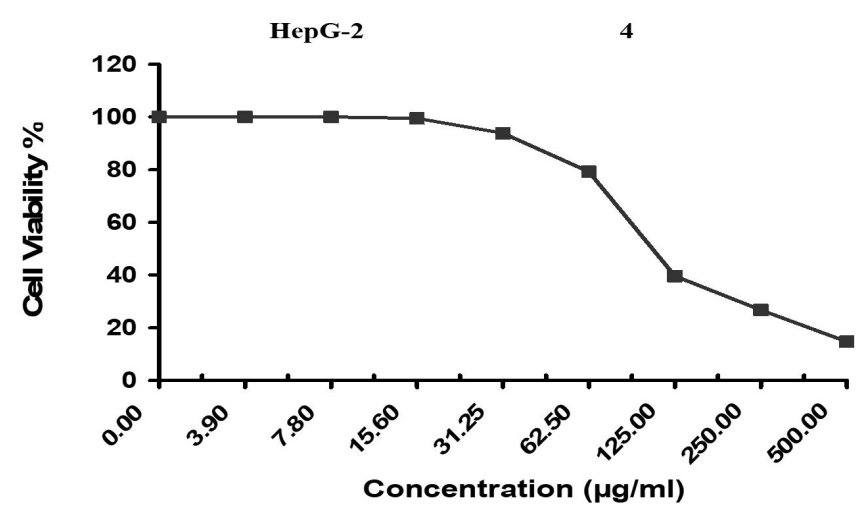

Figure 2. Evaluation of cytotoxicity against HepG-2 cell line; Inhibitory activity against Hepatocellular carcinoma cells was detected under these experimental conditions with $\mathrm{IC}_{50=} 109 \pm 3.6 \mu \mathrm{g} / \mathrm{mL}$.

alchole, steriods, terpinoids and silane. In addition, the presence of some compounds that determined herein by Gc.mass analysis as Carophylla and Tricyclo-carboxylic acid. Also, the presence of ether and pyrazole compounds in A. flavus extract plays major roles as antioxidant and antimicrobial activities. Moreover, the present results confirmed the presence of other bioactive compounds as Spirosten, Naphthalene, Trinolabdan and hexadecene that characterized by their antiproliferative activity.

\section{Discussion}

Natural sources have recently shown a promising interest in treating cancer or inhibiting multidrug pathogenic bacteria as a treatment (Abdel-Shafi et al., 2019, 2020; Enan et al., 2020; Uzma et al., 2018). As they are stable officers, they have an enticing future. In the present analysis, the biological efficacy of certain secondary metabolites as antioxidant, antimicrobial and antitumor was suggested for the filamentous fungi; this finding is in accordance with the observations of Chen et al. (2011); El-Gazzar et al., (2021); El-Bahr et al. (2021). In addition, the present investigation found that $A$. flavus was the most activate fungus similar with that reported with the observations of Tenguria \& Khan's (2011). 


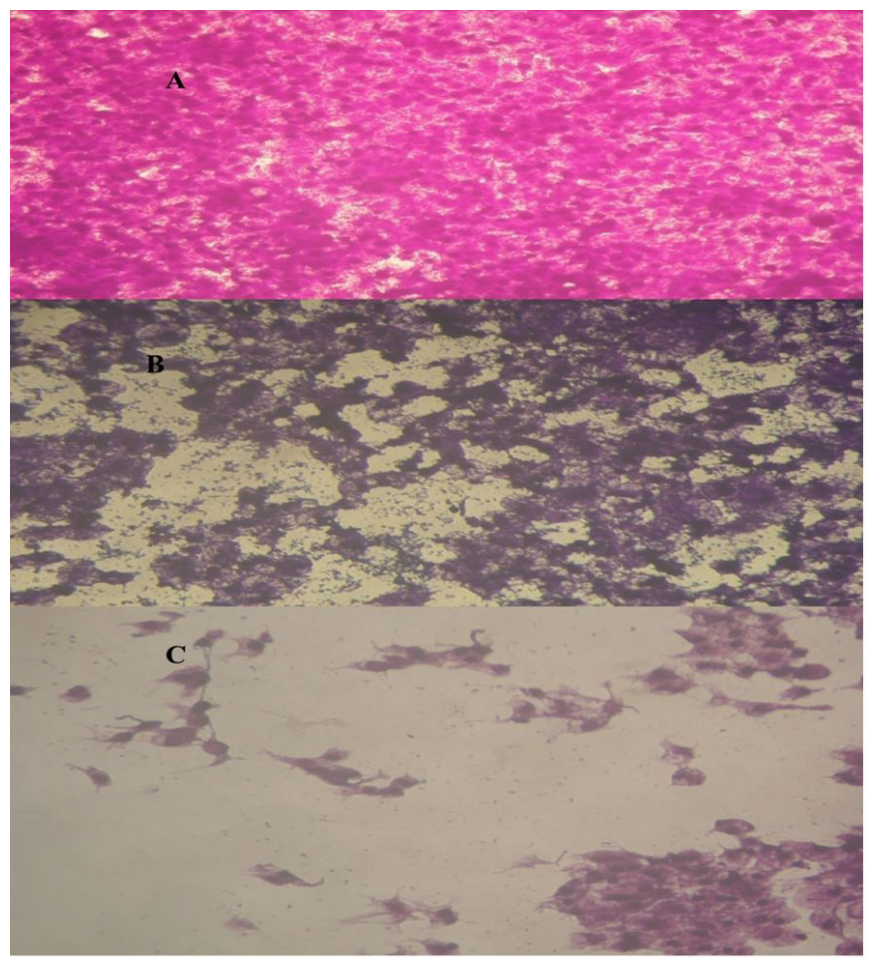

Figure 3. HepG cells treated with A. flavus extract at $10 \mu \mathrm{g}(\mathrm{A})$; at $100 \mu \mathrm{g}(\mathrm{B})$; at $500 \mu \mathrm{g}(\mathrm{C})$.

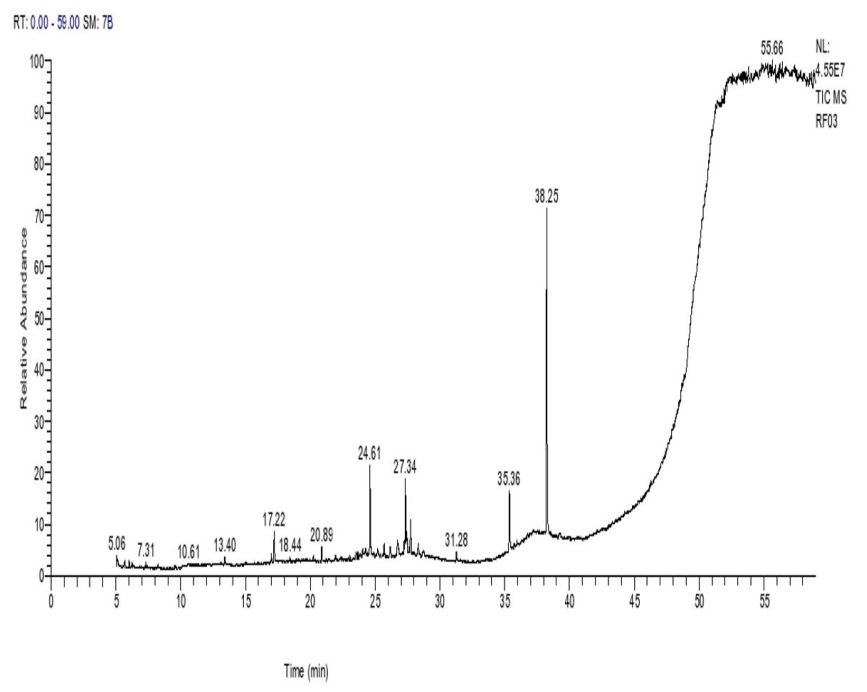

Figure 4. GC-Mass of A. flavus extract.

The characterization of the secondary products of $A$. flavus in this study confirmed the presence of the bioactive compounds similar to other fungal organisms that reported in the previous observations of Frisvad et al. (2008). All metabolites of diverse fungi in the present study showed an antioxidant activity up to varying extent and this concurs with the observations of Kumaresan et al. (2015). In addition, the isolated fungi herein had antioxidant efficiency in vitro. Whereas, the estimation of the bioactive compounds from A. flavus confirmed the existence of diverse natural drugs similar to that reported previously (Abubakar \& Ndana, 2016). Moreover, the results reported the presence of free radical scavenging power of antioxidant components that coincided with other parallel work related to antioxidant activity by Ghasemzadeh et al. (2010). Based on the DPPH assay in the present study, it was apparent that $A$. flavus exhibited strong antioxidant potential $81.4 \% \pm 0.60$ with $\mathrm{IC}_{50}$ at $5 \mu \mathrm{g}$ compared with the $\mathrm{IC}_{50}$ values $(5 \mu \mathrm{g})$ of ascorbic acid which was used as a standard antioxidant $92.48^{\mathrm{a}} \% \pm 2.48$. Regarding to ascorbic acid, the previous studies confirmed that this acid has commonly been used as a standard antioxidant in DPPH assays, considering that ascorbic acid is one of the most powerful natural antioxidants and prominent representatives of dietary antioxidants for human (Sugiharto et al., 2015).

Fungi themselves could be sources of different compounds associated with antioxidant activities (Arora \& Chandra, 2010). In the present study, there are other compounds in the A. flavus extract share in antioxidant, antimicrobian and citotoxity effects as determined by GC/MS analysis. Several studies have revealed that the antioxidant capacity in filamentous fungi was attributed mainly to their flavonoid and phenolics contents that have been determined as major contributions for the antioxidant capacity in fungi beside other bioactive compounds (Arora \& Chandra, 2010).

Herein data suggested that naturalistic potent metabolites isolated from fungi act as sequential provenance for the detection of novel antiproliferative and antibacterial agents and this similar with the previous reports (Jalgaonwala et al., 2017; Tejesvi et al., 2008). Moreover, those effective products possess broad efficiency in medical fields. Thus, the presented results confirmed an exclusive activity of $A$. flavus extract against the HepG2 hepatocellular carcinoma cell line as similar to that confirmed previously by González-Menéndez et al. (2018).

In this connection, the antiproliferative ability of the selected fungal isolate in the present study showed that the fungal secondary extract has antitumor activity due to the presence of bioactive natural compounds. Similarly with the observations of Strobel (2003) who reported the production of diverse forms of bio-effective secondary products combined with most potent sides of flavonoids, phenols, alkaloids, terpenoids and others with their different biological activities.

Gc.Mass analysis in the present study confirmed the presence of some compounds in A.falvus metabolites as alchole, phenol, steriods, terpinoids, silane and others that characterized by their antioxidant, antimicrobial and anticancer activities; this concurs with other previous studies (Verma, 2006; Mou et al., 2013; Kim et al., 2015; Govindappa et al., 2017; Tamil et al., 2017; Karakuş et al., 2018; Al-Romaizan et al., 2019; Purnamasari et al., 2019; Al-Mohammadi et al., 2020). In addition, the presence of some compounds determined herein as Carophylla and Tricyclo-carboxylic acid that reported in the previous studies by their potent anticancer activities (Verma, 2006; Jelena \& Maja, 2015; Al-Romaizan et al., 2019). In this regarding, presence of ether and pyrazole compounds in A. flavus extract play major roles as antioxidant and antimicrobial activities; this concurs with that reported in the previous studies (Jelena \& Maja, 2015; Srivastava et al., 2015; Narra et al., 2017; Yadav et al., 2018). 
Table 7. Chemical composition of 26 components from A. flavus extract when subjected to GC-MS (gas liquid chromoatographic mass spectrometry).

\begin{tabular}{|c|c|c|c|c|c|c|c|c|}
\hline No. & $\begin{array}{l}\text { Retention } \\
\text { Time(Rt) }\end{array}$ & M.formula & M.W. & Compound name and structure & Area & $\begin{array}{c}\text { Parent } \\
\text { ion }\left(\mathrm{M}^{+}\right)\end{array}$ & $\begin{array}{c}\text { Base Peak } \\
(\mathrm{m} / \mathrm{e}) \\
(100 \%) \\
\end{array}$ & Biological activity \\
\hline 1 & 5.71 & $\mathrm{C}_{7} \mathrm{H}_{10} \mathrm{O} 2$ & 126.0 & 2,4-HEXADIENOIC ACID, METHYL ESTER & 3.15 & 126.0 & 67.00 & $\begin{array}{l}\text { Anticancer\& } \\
\text { Antioxidant, } \\
\text { Kim et al. (2015). }\end{array}$ \\
\hline 2 & 7.31 & $\mathrm{C}_{16} \mathrm{H}_{16} \mathrm{O}$ & 224.0 & 1,4-DIPHENYLBUT-3-ENE-2-OL & 0.60 & 224.0 & 207.0 & $\begin{array}{l}\text { Anticancer\& } \\
\text { Antioxidant, } \\
\text { Mou et al. (2013) }\end{array}$ \\
\hline 3 & 7.31 & $\mathrm{C}_{11} \mathrm{H}_{15} \mathrm{NO} 2 \mathrm{~S}$ & 225.0 & $\begin{array}{l}\text { 2-THIOPHENEETHANOL,5-(4,5-DIHYDRO- } \\
\text { 4,4-DIMETHYL-2-OXAZOLYL- }\end{array}$ & 0.60 & 225.0 & 207.0 & $\begin{array}{l}\text { Anticancer \& } \\
\text { Antioxidant, } \\
\text { Karakuş et al. (2018) }\end{array}$ \\
\hline 4 & 17.22 & $\mathrm{C}_{14} \mathrm{H}_{22} \mathrm{O}$ & 206.0 & Phenol, 2,4-Bis(1,1-DIMETHYLETHYL)_ & 5.18 & 206.0 & 191.0 & $\begin{array}{l}\text { Anticancer\& } \\
\text { Antioxidant, } \\
\text { Kim et al. (2015) } \\
\text { Govindappa et al. } \\
\text { (2017) }\end{array}$ \\
\hline 5 & 20.89 & $\mathrm{C}_{15} \mathrm{H}_{24} \mathrm{O}$ & 220.0 & Caryophylla-4(2),8(13)-dien-5a-ol & 1.41 & 220.0 & 136.0 & $\begin{array}{l}\text { Anticancer, } \\
\text { Qsar (41); Al- } \\
\text { Romaizan et al. } \\
\text { (2019) }\end{array}$ \\
\hline 6 & 21.95 & $\mathrm{C}_{18} \mathrm{H}_{16} \mathrm{O}_{7}$ & 344.0 & $\begin{array}{l}\text { 4H-1-BENZOPYRAN-4-ONE,2-(3,4- } \\
\text { DIMETHOXYPHENYL)-3,5-DIHYDROXY-7- } \\
\text { METHOXY- }\end{array}$ & 11.57 & 344.0 & 57.0 & $\begin{array}{l}\text { Antioxidant, } \\
\text { Tamil et al. } \\
\text { (2017), Al- } \\
\text { Mohammadi et al. } \\
\text { (2020), }\end{array}$ \\
\hline 7 & 23.53 & $\mathrm{C}_{29} \mathrm{H}_{43} \mathrm{NO}_{3} \mathrm{Si}$ & 481.0 & $\begin{array}{l}\text { ANDROSTANE-11,17-DIONE,3- } \\
\text { [(TRIMETHYLE SILYL) OXY]-17-[O- } \\
\text { (PHENYLMETHYL)OXIME],(3a,5a) }\end{array}$ & 0.83 & 481.0 & 73.0 & $\begin{array}{l}\text { Anticancer \& } \\
\text { Antioxidant, } \\
\text { Purnamasari et al. } \\
\text { (2019) ; Jelena } \\
\text { \& Maja (2015); } \\
\text { Yadav et al. (2018), }\end{array}$ \\
\hline 8 & 23.68 & $\mathrm{C}_{12} \mathrm{H}_{18} \mathrm{O}_{2}$ & 194.0 & $\begin{array}{l}\text { Tricyclo }[4,3,1,1(3,8)] \text { undecane-3-carboxylic } \\
\text { acid }\end{array}$ & 0.84 & 194.0 & 149.0 & $\begin{array}{l}\text { Anticancer, Jelena \& } \\
\text { Maja (2015) }\end{array}$ \\
\hline 9 & 23.87 & $\mathrm{C}_{24} \mathrm{H}_{34} \mathrm{O}_{5}$ & 402.0 & $\begin{array}{l}\text { 1,2,3,4,4a,5,6,7,8,8a,9- } \\
\text { Dodecahydrophenanthren-9-one,2- } \\
\text { acetoxy-7-methylene-1,1,4a-trimethyl-8-(2- } \\
\text { methoxycarbonylethyl)- }\end{array}$ & 1.40 & 402.0 & 43.0 & $\begin{array}{l}\text { Anticancer \& } \\
\text { Antioxidant } \\
\text { (Purnamasari et al., } \\
\text { 2019) }\end{array}$ \\
\hline 10 & 24.05 & $\mathrm{C}_{23} \mathrm{H}_{32} \mathrm{O}$ & 324.0 & $\begin{array}{l}\text { 2-[4-methyl-6-(2,6,6-trimethylcyclohex-1- } \\
\text { enyl)hexa-1,3,5-trienyl] cyclohex-1-en-1- } \\
\text { carboxaldehde }\end{array}$ & 2.18 & 324.0 & 43.0 & $\begin{array}{l}\text { Anticancer \& } \\
\text { Antioxidant, } \\
\text { Karakuş et al. (2018) }\end{array}$ \\
\hline 11 & 24.61 & $\mathrm{C}_{17} \mathrm{H}_{34} \mathrm{O}_{2}$ & 270.0 & Hexadecanoic acid, methyl ester & 37 & 270.0 & $\begin{array}{c}74.0 \& \\
87.0\end{array}$ & $\begin{array}{l}\text { Anticancer\& } \\
\text { Antioxidant, } \\
\text { Narra et al. (2017), }\end{array}$ \\
\hline 12 & 25.70 & $\mathrm{C}_{18} \mathrm{H}_{36} \mathrm{O}_{2}$ & 284.0 & Pentadecanoic acid, 14 methyl-, ethyl ester & 4.23 & 284.0 & 88.0 & $\begin{array}{l}\text { Anticancer\& } \\
\text { Antioxidant, } \\
\text { Narra et al. (2017), }\end{array}$ \\
\hline 13 & 26.18 & $\mathrm{C}_{32} \mathrm{H}_{58} \mathrm{OSi}$ & 486.0 & Silane, trimethyl (stigmast-5-en-3beta-yloxy)- & 4.87 & 486.0 & 73.0 & $\begin{array}{l}\text { Antioxidant activity, } \\
\text { Yadav et al. (2018), }\end{array}$ \\
\hline 14 & 26.18 & $\mathrm{C}_{30} \mathrm{H}_{53} \mathrm{NO}_{4} \mathrm{Si}$ & 519.0 & $\begin{array}{l}\text { Glycine, N-[(3alpha,5beta)-24-oxo-3- } \\
{[(\text { trimethyl silyl) oxy]cholan-24-yl]-, methyl }} \\
\text { ester }\end{array}$ & 2.82 & 519.0 & 131.0 & $\begin{array}{l}\text { Antioxidant activity, } \\
\text { Yadav et al. (2018), }\end{array}$ \\
\hline 15 & 26.73 & $\mathrm{C}_{30} \mathrm{H}_{52} \mathrm{O}_{2}$ & 444.0 & $\begin{array}{l}\text { 2,6,10,15,19,23-hexamethyl-2,6,14,18,22- } \\
\text { tetracosapentaene-10,11-diol }\end{array}$ & 5.62 & 444.0 & 69.0 & $\begin{array}{l}\text { Antioxidant, } \\
\text { Srivastava et al. } \\
\text { (2015), }\end{array}$ \\
\hline 16 & 26.73. & $\mathrm{C}_{23} \mathrm{H}_{38} \mathrm{O}_{2}$ & 346.0 & $6,9,12,15$-Docosatetraenoic acid, methyl ester & 2.81 & 346.0 & 69.0 & $\begin{array}{l}\text { Antioxidant } \\
\text { (Srivastava et al. } \\
\text { (2015), }\end{array}$ \\
\hline 17 & 27.34 & $\mathrm{C}_{19} \mathrm{H}_{36} \mathrm{O}_{2}$ & 296.0 & 9-octadecenoic acid, methyl ester, (E)- & 19.26 & 296.0 & 55.0 & $\begin{array}{l}\text { Antioxidant } \\
\text { (Narra et al. (2017) }\end{array}$ \\
\hline
\end{tabular}


Table 7. Continued...

\begin{tabular}{|c|c|c|c|c|c|c|c|c|}
\hline No. & $\begin{array}{l}\text { Retention } \\
\text { Time(Rt) }\end{array}$ & M.formula & M.W. & Compound name and structure & Area & $\begin{array}{c}\text { Parent } \\
\text { ion }\left(\mathrm{M}^{+}\right)\end{array}$ & $\begin{array}{c}\text { Base Peak } \\
(\mathrm{m} / \mathrm{e}) \\
(100 \%)\end{array}$ & Biological activity \\
\hline 18 & 27.44 & $\mathrm{C}_{27} \mathrm{H}_{104} \mathrm{O}_{6}$ & 884.0 & $\begin{array}{l}\text { 9-Octadecenoic acid,1,2,3-propanetriyl ester, } \\
(\mathrm{E}, \mathrm{E}, \mathrm{E})\end{array}$ & 1.77 & 884.0 & 55.0 & $\begin{array}{l}\text { Antioxidant } \\
\text { (Srivastava et al. } \\
(2015)\end{array}$ \\
\hline 19 & 27.64 & $\mathrm{C}_{27} \mathrm{H}_{40} \mathrm{O}_{4}$ & 428.0 & $\begin{array}{l}\text { Spirost-8-en-11-one,3-hydroxy- } \\
,(3 \mathrm{a}, 5 \mathrm{a}, 14 \mathrm{a}, 20 \mathrm{a}, 22 \mathrm{a}, 25 \mathrm{R})\end{array}$ & 1.99 & 428.0 & 314.0 & $\begin{array}{l}\text { Anticancer, } \\
\text { antibacterial and } \\
\text { antioxidant (Lu et al. } \\
\text { (2015) }\end{array}$ \\
\hline 20 & 27.74 & $\mathrm{C}_{19} \mathrm{H}_{38} \mathrm{O}_{2}$ & 298.0 & Heptadecanoic acid, 16-methyl-, methyl ester & 13 & 298.0 & 74.0 & $\begin{array}{l}\text { Antioxidant } \\
\text { (Naganna et al., }\end{array}$ \\
\hline 21 & 28.34 & $\mathrm{C}_{29} \mathrm{H}_{50} \mathrm{O} 2$ & 430.0 & $\begin{array}{l}\text { Cholestan-3-ONE,Cyclic 1,2-Ethanediyl Aetal,* } \\
\text { (5 a)- }\end{array}$ & 2.62 & 430.0 & 99.0 & $\begin{array}{l}\text { Anticancer \& } \\
\text { Antioxidant } \\
\text { (Sisa et al. (2003) }\end{array}$ \\
\hline 23 & 31.28 & $\mathrm{C}_{19} \mathrm{H}_{24} \mathrm{~N}_{2}$ & 280.0 & Curan, 16,17-didehydro-,(20.xi.)- & 2.62 & 280.0 & 55.0 & $\begin{array}{l}\text { Anticancer } \\
\text { (Mou et al. (2013) }\end{array}$ \\
\hline 24 & 35.36 & $\mathrm{C} 24 \mathrm{H} 38 \mathrm{O} 4$ & 390.0 & Bis(2-ETHYLHEXYL)PHTHALATE & 6.68 & 390.0 & 149.0 & $\begin{array}{l}\text { Antioxidant } \\
\text { Lemoreaux }\end{array}$ \\
\hline 25 & 38.25 & $\mathrm{C}_{21} \mathrm{H}_{18} \mathrm{O}_{6}$ & 366.0 & $\begin{array}{l}\text { 9-Carbomethyl-6,11-DIMETHOXY-5- } \\
\text { OXO-9,10-DIHydroXANTHO[3,2-G] } \\
\text { NAPHTHALENE }\end{array}$ & 29.72 & 366.0 & 307.0 & $\begin{array}{l}\text { Anticancer, } \\
\text { Zheng et al.,2018) }\end{array}$ \\
\hline 26 & 38.25 & $\mathrm{C}_{19} \mathrm{H}_{33} \mathrm{NO}_{2}$ & 307.0 & $\begin{array}{l}\text { 12-ACETYLAMINO-15,16,17- } \\
\text { TRINORLABDAN-8-ONE }\end{array}$ & 59.44 & 307.0 & 292.0 & $\begin{array}{l}\text { Anticancer and } \\
\text { antimicrobial, El- } \\
\text { Sayed et al. (2020), } \\
\text { Popova et al. (2009), }\end{array}$ \\
\hline
\end{tabular}

Moreover, the present investigation confirmed the presence of other bioactive compounds as Spirosten, Naphthalene, Trinolabdan and hexadecene that characterized by their antiproliferative activity, similarly with that reported previously (Huang et al., 2003; Sisa et al., 2003; Popova et al., 2009; Lu et al., 2015; Lemoreaux, 2017; Zheng et al., 2018).

\section{Conclusion}

The present study confirmed the efficient role of fungal bioactive products as strong in vitro antioxidant, antimicrobial and antiproliferative activities. Performing the GC-MS analysis of $A$. flavus extract, with potent phytochemicals confirmed its ability to induce the antiproliferative mechanism. The results indicated that the $A$. flavus had a potent naturalistic constituent in cytotoxicity. Additional researches are in demand for purification the bioactive products which can be discussed as efficient antiproliferative drugs.

\section{Acknowledgements}

The research project was supported by grant from the research center of the female scientific and medical colleges, Deanship of Scientific Research, King Saud University. Riyadh, Saudi Arabia. Also, the authors thank Prof. Dr Gamal Enan, Dean of Faculty of science, Zagazig University, Egypt for his critical revising the manuscript.

\section{References}

Abdel-Shafi, S., Osman, A., Enan, G., El-Nemer, M., \& Sitohy, M. (2016). Antibacterial activity of methylated egg white proteins against pathogenic $\mathrm{G}^{+}$and $\mathrm{G}^{-}$bacteria matching antibiotics. SpringerPlus, 5(1), 983-995. http://dx.doi.org/10.1186/s40064-016-2625-3. PMid:27429892.

Abdel-Salam, H. A., El-Khamissy, T., Enan, G. A., \& Hollenberg, C. P. (2001). Expression of mouse anticreatine kinase (MAK33) monoclonal antibody in the yeast Hansenula polymorpha. Applied Microbiology and Biotechnology, 56(1-2), 157-164. http://dx.doi. org/10.1007/s002530000572. PMid:11499924.

Abdel-Shafi, S., Al-Mohammadi, A. R., Osman, A., Enan, G., AbdelHameid, S., \& Sitohy, M. (2019). Characterization and antibacterial activity of $7 \mathrm{~s}$ and $11 \mathrm{~s}$ globulins isolated from cowpea seed protein. Molecules, 24(6), 1082. http://dx.doi.org/10.3390/molecules24061082. PMid:30893826.

Abdel-Shafi, S., Al-Mohammadi, A.-R., Almanaa, T. N., Moustafa, A. H., Saad, T. M. M., Ghonemey, A.-R., Anacarso, I., Enan, G., \& El-Gazzar, N. (2020). Identification and testing antidermatophytic oxaborole6-benzene sulphonoamide derivative (OXBS) from Streptomyces atrovirens KM192347 isolated from soil. Antibiotics, 9(4), 176. http:// dx.doi.org/10.3390/antibiotics9040176. PMid:32294942.

Abubakar, S., \& Ndana, R. W. (2016). Preliminary study of endomyco diversity among three ethnomedicinal plants from family Meliaceae in Nigeria. Journal of BioScience and Biotechnology, 5, 195-201.

Al-Mohammadi, A.-R., Osman, A., Enan, G., Abdel Shafi, S., El-Nemer, M., Sitohy, M., \& Taha, M. A. (2020). Powerful antibacterial peptides 
from egg albumin hydrolysates. Antibiotics, 9(12), 901. http://dx.doi. org/10.3390/antibiotics9120901. PMid:33322196.

Al-Romaizan, A. N., Jaber, T. S., \& Ahmed, N. S. (2019). Novel 1, 8-naphthyridine derivatives: design, synthesis and in vitro screening of their cytotoxic activity against MCF7 cell line. Open Chemistry, 17(1), 943-954. http://dx.doi.org/10.1515/chem-2019-0097.

Arora, D. S., \& Chandra, P. (2010). Assay of antioxidant potential of two Aspergillus isolates by different methods under various physio-chemical conditions. Brazilian Journal of Microbiology, 41(3), 765-777. http:// dx.doi.org/10.1590/S1517-83822010000300029. PMid:24031554.

Aziz, N., Fatma, T., Varma, A., \& Prasad, R. (2014). Biogenic synthesis of silver nanoparticles using Scenedesmus abundans andevaluation of their antibacterial activity. Journal of Nanoparticles, 2014, 689419. http://dx.doi.org/10.1155/2014/689419.

Baba, S. A., \& Malik, S. A. (2015). Determination of total phenolic and flavonoid content, antimicrobialand antioxidant activity of a root extract of Arisaema jacquemontii Blume. Journal of Taibah University for Science, 9(4), 449-454. http://dx.doi.org/10.1016/j. jtusci.2014.11.001.

Booth, C. (1971). The genus Fusarium. Kew: Commonwealth Mycological Institute.

Chen, I. C., Hill, J. K., Ohlemuller, R., Roy, D. B., \& Thomas, C. D. (2011). Rapid range shifts of species associated with high levels of climate warming. Science, 333(6045), 1024-1026. http://dx.doi. org/10.1126/science.1206432. PMid:21852500.

Dedio, W., Kaltsikes, P. S., \& Larter, E. N. (1969). A thin layer chromatographic study of the phenols in Triticale and its parents. Canadian Journal of Botany, 47(10), 15-89. http://dx.doi.org/10.1139/ b69-227.

El-Gazzar, N. S. (2015). Continuous production of nanometal by some fungi isolated from heavy metal polluted habitats ( $\mathrm{PhD}$ thesis). Faculty of Science, Zagazig University, Zagazig, Egypt.

El-Gazzar, N. S., \& Enan, G. (2020). Advances in phage inspired nanoscience based therapy. In S. K. Saxena \& S. M. Paul Khurana (Eds.), NanoBioMedicine (Chap. 10, pp. 237-257). Singapore: Springer Nature. http://dx.doi.org/10.1007/978-981-32-9898-9_10.

El-Gazzar, N., \& Ismail, A. M. (2020). The potential use of Titanium, Silver and Selenium nanoparticles in controlling leaf blight of tomato caused by Alternaria alternata. Biocatalysis and Agricultural Biotechnology, 27, 101708. http://dx.doi.org/10.1016/j.bcab.2020.101708.

El-Gazzar, N., Almaary, K., Ismail, A., \& Polizzi, G. (2020). Influence of Funneliformis mosseae enhanced with titanium dioxide nanoparticles ( $\mathrm{TiO}_{2} \mathrm{NPs}$ ) on Phaseolus vulgaris L. under salinity stress. PLoS One, 15(8), e0235355. http://dx.doi.org/10.1371/journal.pone.0235355. PMid:32817671.

El-Gazzar, N., Almanaa, N,T., Reda,M,R., El Gaafary,N.M., Rashwan, A.A., Mahsoub,F.(2021). Assessment the using of silica nanoparticles ( $\mathrm{SiO} 2 \mathrm{NPs}$ ) biosynthesized from rice husks by Trichoderma harzianum MF 780864 as water lead absorbent for immune status of Nile tilapia (Oreochromis niloticus). Saudi Journal of Biological Sciences, S1319-562X(21):00395-8. http://doi.org/10.1016/j.sibs.2021.05.027.

El-Bahr, M. S., Elbakery, M. A., El-Gazzar, N., Amin, A. A., Al-Sultan, S., Alfattah, M., Shousha, S., Alhojaily, S., Shathele, M., Sabeq, I., \& Hamouda, A. (2021). Biosynthesized Iron Oxide Nanoparticles from Petroselinum crispum Leaf Extract Lead- Acetate- Induced Anemia in Male Albino Rats: Hematological, Biochemical and Histopathological Features. Toxics, 9(6), 123. http://dx.doi.org/10.3390/ toxics9060123. PMid:34072696.

El-Sayed, A., Enan, G., Al-Mohammadi, A. R., Moustafa, A., \& ElGazzar, N. (2020). Detection, purification, elucidation of chemical structure and antiproliferative activity of taxol produced by Penicillium chrysogenum. Molecules, 25(20), 4822. http://dx.doi.org/10.3390/ molecules25204822.

Enan, G., Abdel-Shafi, S., Ouda, S., \& Negm, S. (2013). Characterization of probiotic lactic acid bacteria to be used as starter culture and protective cultures for diary fermentations. International Journal of Probiotics \& Prebiotics, 8(4), 157-163.

Enan, G., Al-Mohammadi, A.-R., Mahgoub, S., Abdel-Shafi, S., Askar, E., Ghaly, M. F., Taha, M. A., \& El-Gazzar, N. (2020). Inhibition of Staphylococcus aureus LC554891 by Moringa oleifera seed extract either singly or in combination with antibiotic. Molecules, 25(19), 20-29. http://dx.doi.org/10.3390/molecules25194583. PMid:33036497.

Enan, G., Osman, M. E., Abdel-Haliem, M. E. F., \& Abdel-Ghany, S. E. (2018). Advances in microbial and nucleic acids biotechnology. BioMed Research International, 1-2, 3102374. http://dx.doi. org/10.1155/2018/3102374. PMid:30035120.

Frisvad, J. C., Andersen, B., \& Thrane, U. (2008). The use of secondary metabolite profiling in chemotaxonomy of filamentous fungi. Mycological Research, 112(Pt 2), 231-240. http://dx.doi.org/10.1016/j. mycres.2007.08.018. PMid:18319145.

Ghasemzadeh, A., Jaafar, H. Z. E., \& Rahmat, A. (2010). Elevated carbon dioxide increases contents of flavonoids and phenolic compounds, and antioxidant activities in malaysian young ginger (Zingiber officinale Roscoe.) varieties. Molecules, 1(5), 7451-7466. http://dx.doi.org/10.3390/molecules15117907. PMid:21060298.

González-Menéndez, V., Crespo, G., Pedro, N., Diaz, C., Martín, J., Serrano, R., Mackenzie, T. A., Justicia, C., González-Tejero, M. R., Casares, M., Vicente, F., Reyes, F., Tormo, J. R., \& Genilloud, O. (2018). Fungal endophytes from arid areas of Andalusia: high potential sources for antifurrgal and antitumoral agents. Scientific Reports, 8(1), 9729. http://dx.doi.org/10.1038/s41598-018-28192-5. PMid:29950656.

Govindappa, M., Shilpashree, C. C., \& Bharathi, P. (2017). In vitro antimitotic antiproliferative and GC-MS studies on the methanolic extract of endophytic fungi, Penicillium species of Tabebuia argentea Bur \& K. Sch. Farmacia, 65, 2.

Huang, H., Jia, Q., Ma, J., Qin, G., Chen, Y., Xi, Y., Lin, L., Zhu, W., Ding, J., Jiang, H., \& Liu, H. (2009). Discovering novel quercetin-3$\mathrm{O}$-amino acid-esters as a new class of Src tyrosine kinase inhibitors. European Journal of Medicinal Chemistry, 44(5), 1982-1988. http:// dx.doi.org/10.1016/j.ejmech.2008.09.051. PMid:19041163.

Huang, M. H., Wu, S. N., Wang, J. P., Lin, H. C., Lu, I. S., Liao, L. I., \& Shen, A. Y. (2003). Biological study of naphthalene derivatives with anti-inflammatory acticities. Drug Development Research, 60(4), 261-269. http://dx.doi.org/10.1002/ddr.10327.

Jalgaonwala, R. E., Mohite, H. V., \& Mahajan, R. T. (2017). A review: natural products from plant associated endophyic fungi. Journal of Microbiology and Biotechnology Research, L, 21-32.

Jelena, K., \& Maja, M. (2015). Natural and synthetic coumarins as potential anticancer agents. Journal of Chemical and Pharmaceutical Research, 7(7), 1223-1238.

Karakuş, S., Tok, F., Türk, S., Salva, E., Tatar, G., Taskın-Tok, T., \& Kocyigit-Kaymakcioglu, B. (2018). Synthesis, anticancer activity and ADMET studies of N- (5-methyl-1, 3, 4-thiadiazol-2-yl) - 4[(3-substituted) ureido/ thioureido] benzene sulfonamide derivatives. Journal Phosphorus, Sulfur, and Silicon and the Related Elements, 193(8), 528-534. http://dx.doi.org/10.1080/10426507.2018.1452924.

Kim, J. H., Lee, Y., Sung, G. H., Kim, H. G., Jeong, D., Park, J. G., Baek, K. S., Sung, N. Y., Yang, S., Yoon, D. H., Lee, S. Y., Kang, H., Song, C., Cho, J. H., Lee, K. H., Kim, T. W., \& Cho, J. Y. (2015). Antiproliferative and Apoptosis-Inducing Activities of 4-Isopropyl-2, 
6-bis (1-phenylethyl) phenol Isolated from Butanol Fraction of Cordyceps bassiana. Evidence-Based Complementary and Alternative Medicine, 2015, 739874. http://dx.doi.org/10.1155/2015/739874. PMid:25918546.

Kumaresan, S., Karthi, V., Senthilkumar, V., Balakumar, B. S., \& Stephen, A. (2015). Biochemical constituents and antioxidant potential of endophytic fungi isolated from the leaves of Azadirachta indica A. Juss) Neem) from Chennaii, India. Journal of Academia and Industrial Research, 3, 355-361.

Lemoreaux, P. (2017). Two quarter horse trainers suspended for drug violations at prairie meadows. Daily Racing Form.

Lu, X. F., Yang, Z., Huang, N. U., He, H. B., Deng, W.-Q., \& Zou, K. (2015). Synthesis and cytotoxic activities of 2-substituted (25R)-spirostan1,4,6-triene-3-ones via ring-opening/elimination and 'click' strategy. Bioorganic \& Medicinal Chemistry Letters, 25(17), 3726-3729. http:// dx.doi.org/10.1016/j.bmcl.2015.06.028. PMid:26141770.

Melo, E. A., Maciel, M. I. S., Galvao, D. E., Lima, V. L. A., \& Rodrigues de Araujo, C. (2008). Total phenolic content and antioxidant capacity of frozen fruit pulps. Alimentos e Nutrição, 19, 67-72.

Mosmann, T. (1983). Rapid colorimetric assay for cellular growth and survival application to proliferation and cytotoxicity assays. Journal of Immunological Methods, 65(1-2), 55-63. http://dx.doi. org/10.1016/0022-1759(83)90303-4. PMid:6606682.

Mou, Y., Meng, J., Fu, X., Wang, X., Tian, J., Wang, M., Peng, Y., \& Zhou, L. (2013). Antimicrobial and antioxidant activities and effect of 1-hexadecene addition on palmarumycin $\mathrm{C}_{2}$ and $\mathrm{C}_{3}$ yields in liquid culture of endophytic fungus Berkleasmium sp. Dzf12. Molecules, 18(12), 15587-15599. http://dx.doi.org/10.3390/molecules181215587. PMid:24352015.

Narra, N., Kaki, S. S., Prasad, R. B. N., Misra, S., Dhevendar, K., Kontham, V., \& Korlipara, P. V. (2017). Synthesis and evaluation of anti-oxidant and cytotoxic activities of novel 10-undecenoic acid methyl ester based lipoconjugates of phenolic acids. Beilstein Journal of Organic Chemistry, 13, 26-32. http://dx.doi.org/10.3762/ bjoc.13.4. PMid:28179945.

Osman, A., El-Gazzar, N., Almanaa, T. N., El-Hadary, A., \& Sitohy, M. (2021). Lipolytic postbiotic from Lactobacillus paracasei manages metabolic syndrome in albino wistar rats. Molecules, 26(2), 472. http://dx.doi.org/10.3390/molecules26020472. PMid:33477482.

Popova, M. P., Chinou, I., Marekov, I. N., \& Bankova, V. (2009). Terpenes with antimicrobial activity from Cretan propolis. Phytochemistry, 70(10), 1262-1271. http://dx.doi.org/10.1016/j.phytochem.2009.07.025. PMid:19698962.

Purnamasari, R., Winarni, D., Permanasari, A. A., Agustina, E., Hayaza, S., \& Darmanto, W. (2019). Anticancer activity of methanol extract of Ficus carica leaves and fruits against proliferation, apoptosis, and necrosis in Huh7it cells. Cancer Informatics, 18. http://dx.doi. org/10.1177/1176935119842576. PMid:31037025.

Raper, K. B., \& Fennell, D. I. (1965). The genus Aspergillus. Baltimore: Williams and Wilkins.

Raper, K. B., \& Thom, C. (1949). A manual of Penicillia. Baltimore: Williams and Wilkins.

Ronsberg, D. A., Debbab, A., Mantli, V., Wray, I., Dai, T., Kurtatr, P. P., \& Aly, A. H. (2013). Secondary metabolites from the endophytic fungus Pestolotiop,sis virgotulo isolated from the mangrove plant Sonnerut io coseolaris. Tetrah. Lett, 54, 3256-3259.

Shi, Z., Peng, X. X., Kim, I. W., Shukla, S., Si, Q. S., Robey, R. W., Bates, S. E., Shen, T., Ashby, C. R. Jr., Fu, L. W., Ambudkar, S. V., \& Chen, Z. S. (2007). Erlotinib (Tarceva, OSI-774) antagonizes ATP binding cassette subfamily B member 1 and ATP-binding cassette subfamily G member 2- mediated drug resistance. Cancer Research, 67(22),
11012-11020. http://dx.doi.org/10.1158/0008-5472.CAN-07-2686. PMid:18006847.

Simmons, T. L., Andrianasolo, E., McPhail, K., Flatt, P., \& Gerwick, W. H. (2005). Marine natural products as anticancer drugs. Molecular Cancer Therapeutics, 4(2), 333-342. PMid:15713904.

Sisa, M., Budessinsky, M., \& Kohout, L. (2003). Synthesis and biological activity of 7a-homo- and 7a,7b-dihomo-5a-cholestane analogues of brassinolide. Collection of Czechslovak Chemical Communicate, 68(11), 2171.

Srivastava, R., Mukerjee, A., \& Verma, A. (2015). GC-MS Analysis of Phytocomponents in, Pet Ether Fraction of Wrightia tinctoria Seed. Pharmacognosy Journal, 7(4), 249-253. http://dx.doi.org/10.5530/ pj.2015.4.7.

Strobel, G. A. (2003). Endophytes as sources of bioactive products. Microbes and Infection, 5(6), 535-544. http://dx.doi.org/10.1016/ S1286-4579(03)00073-X. PMid:12758283.

Sugiharto, S., Yudiarti, T., \& Isroli, I. (2015). Functional properties of filamentous fungi isolated from the Indonesian fermented dried cassava, with particular application on poultry. Mycobiology, 43(4), 415-422. http://dx.doi.org/10.5941/MYCO.2015.43.4.415. PMid:26839501.

Suryanarayanan, T. S., Thirunavukkarasu, N., Govindarajulu, M. B., Sasse, F., Jansen, R., \& Murali, T. S. (2009). Fungal endophytes and bioprospecting. Fungal Biology Reviews, 23(1-2), 9-19. http://dx.doi. org/10.1016/j.fbr.2009.07.001.

Tamil, N., Devakumar, J., Keerthana, V., \& Sudha, S. (2017). Idetification of bioactives compounds by gas chromatography-mass pectrometry analysis of Syzgium jambos (L.) collected from Western Ghats region Coimbatore. Asian Journal of Pharmaceutical and Clinical Research, 10(1).

Tejesvi, M. V., Kini, K. R., Prakash, H. S., Subbiah, V., \& Shetty, H. S. (2008). Antioxidant, antihypertensive, and antibacterial properties of endophyic Pestalotiopsis species from medicinal plants. Canadian Journal of Microbiology, 54(9), 769-780. http://dx.doi.org/10.1139/ W08-070. PMid:18772940.

Tenguria, R. K., \& Khan, F. N. (2011). Distribution of endophytic fungi in leaves of Azadirachta indica A. JUSS. (Neem) of Panchrnarhi Biosphere Reserve. Current Biotica, 2(2), 27-29.

Uzma, F., Mohan, C. D., Hashem, A., Konappa, N. N. I., Rangappa, S., Kamath, P. V., Singh, B. P., Mudili, V., Gupta, V. K., Siddaiah, C. V., Chowdappa, S., Alqarawi, A. A., \& Abd Allah, E. F. (2018). Endophytic fungi alternative sources of cytotoxic compounds. Frontiers in Pharmacology, 26, 9-309. http://dx.doi.org/10.3389/ fphar.2018.00309. PMid:29755344.

Verma, R. P. (2006). Anti-cancer activities of 1,4-Naphthoquinones: a QSAR study. Anti-Cancer Agents in Medicinal Chemistry Formerly Current Medicinal Chemistry, 6(5), 489-499. http://dx.doi. org/10.2174/187152006778226512. PMid:17017857.

Vijayan, P., Raghu, C., Ashok, G., Dhanaraj, S. A., \& Suresh, B. (2004). Antiviral activity of medicinal plant of Nilgiris. Indian. The Journal of Medical Research, 120(1), 24-29. PMid:15299228.

Yadav, A. M., Yadav, S., Kumar, D., Sharma, J. P., \& Yadav, J. P. (2018). In vitro antioxidant activities and GC-MS analysis of different solvent extracts of Acacia nilotica leaves. Indian Journal of Pharmaceutical Sciences, 80(5), 892-902. http://dx.doi.org/10.4172/pharmaceuticalsciences. 1000436.

Zheng, Y., Ouyang, Q., Fu, R., Liu, L., Zhang, H., Hu, X., Liu, Y., Chen, Y., \& Gao, N. (2018). The cyclohexene derivative MC-3129 exhibits antileukemic activity via RhoA/ROCK1/PTEN/PI3K/Akt pathwaymediated mitochondrial translocation of cofilin. Cell Death \& Disease, 9(6), 656. PMid:29844397. 